\title{
Exploring doctorate holders' perceptions of the non-academic labour market and reputational problems they relate to their employment
}

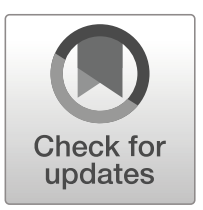

Kati Suomi ${ }^{1}$ (D) Päivikki Kuoppakangas ${ }^{2} \cdot$ Jussi Kivistö $^{2} \cdot$ Jari Stenvall $^{2} \cdot$ Elias Pekkola $^{2}$

Received: 20 June 2019 / Accepted: 28 August 2020 /Published online: 2 September 2020

(C) The Author(s) 2020

\begin{abstract}
Doctoral employment outside universities has been increasing, as universities cannot employ all doctorate holders. Nevertheless, it has been argued that the shift from doctoral programs to the non-academic labour market has been limited. In this qualitative study, more than 800 verbal answers given by doctorate holders to a pair of open-ended questions were content-analysed to explore doctorate holders' perceptions of the nonacademic labour market and the reputational problems they relate to their employment. The study identifies four reputational problems which doctorate holders relate to their employment: the oversupply problem, the overeducation problem, the consistency problem and the communication problem. By identifying potential reputational problems on the doctorate holders level, this research contributes novel information in terms of both theory development and practitioner insights.
\end{abstract}

Keywords Reputation · Doctorate holders · PhDs · Universities · Higher education · University

\section{Introduction}

The labour market for doctorate holders is segmented into jobs at universities and research institutes on one hand, where doctorate holders' qualifications and skills are acknowledged and widely used, and on the other, into jobs outside academia in the non-academic labour market, in the public and private sectors, where such recognition is often lower (Di Paolo and Mañé 2016). According to several studies (Hancock and Walsh 2016; McAlpine and Emmioğlu 2015; Thune 2009), an increasing number of doctorate holders in many countries are seeking employment in labour markets outside universities and research institutes, since

Kati Suomi

kati.suomi@utu.fi

1 University of Turku, P.O. Box 170 28101, Pori, Finland

2 Tampere University, 33100 Tampere, Finland 
the number of academic jobs has not grown in proportion to the number of graduates. This is also true in Finland, the context of the current study. Doctoral employment outside universities has been increasing, because universities cannot employ all doctorate holders, and the government's higher education and science policy highlights the requirement for specialized research capacity in non-academic sectors. One would expect that the highest academic degree would add value to labour markets; however, it has been argued that the shift from doctoral programmes to employment outside academia has been limited (Haapakorpi 2017).

Employers in the non-academic labour market tend not to consider a doctoral degree per se as an important recruitment criterion. Employers are more interested in what an employee can do and what kind of added value s/he is able to bring to an organisation. Indeed, employers particularly appreciate an employee's ability to work independently and absorb new things as well as their knowledge of their field, perseverance, problem-solving skills and critical thinking, qualities for which a doctoral degree provides excellent preparedness. Doctorate holders can also be considered a link between academia and the non-academic labour market and also as those bringing image value to an organisation (Ministry of Education and Culture 2016). However, if employers neither know doctorate holders personally nor have their own prior experience of employing doctorate holders, and particularly if their images of doctorate holders are negative, one can presume that doctorate holders may not be able to proceed in recruitment processes in the non-academic labour market. That said, building a favourable reputation and communicating doctorate holders' competencies is still important, because academia cannot provide employment for all doctorate holders (see also Haapakorpi 2017).

In prior reputation literature, research examining individuals' personal reputations has suggested that developing and maintaining personal reputation is important at any phase of one's working career, as a solid personal reputation reduces uncertainty about a person in the workplace. Indeed, it is suggested that a favourable personal reputation has an impact on employees' career success, autonomy and power (Zinko et al. 2012).

Against this backdrop, we adopt doctorate holders' perspectives, the purpose of the study being to explore their perceptions of the non-academic labour market and reputational problems they relate to their employment. Our literature review shows that previous research has largely ignored this topic. Prior studies focusing on the theoretical construct of reputation and its formation and management have been conducted on different levels, such as the individual, organisational and industry levels (Suomi and Järvinen 2013), but more seldom on the group level, for example focusing on a certain occupation or degree, as in the current study. However, some studies have discussed the reputations of various occupations and occupational communities, such as the accounting community (e.g. Lawrence 1998). In the context of higher education, prior research has examined the effects of professor reputation versus first impressions on student evaluations of instruction, for example (Buchert et al. 2008).

The literature has examined reputation and reputational problems in both private sector firms (e.g. Suomi and Järvinen 2013) and, increasingly, in public sector organisations (e.g. Aula and Tienari 2011). Prior studies have also covered reputation-related issues at the education sector level (e.g. Luoma-Aho 2008) among universities (e.g. Ali-Choudhury et al. 2009; Alves and Raposo 2010), among schools (e.g. Argenti 2000) and among distinct educational programs (e.g. Suomi 2014; Suomi et al. 2014). However, to our knowledge, previous studies have neglected the discussion on reputation and potential reputational problems that doctorate holders relate to their employment in the non-academic labour market, although this topic might shed further light on reasons for doctorate holders' limited 
employment outside academia (Haapakorpi 2017). The study adopts doctorate holders' perspectives, interested in the group which that has been largely ignored in previous studies: doctorate holders who have exited academia (see also Kuoppakangas et al. 2019; Suomi et al. 2019). By addressing potential reputational problems at the doctoral level as doctorate holders themselves perceive them in relation to their employment in the non-academic labour market, the present study will contribute to the knowledge of reputation management in terms of both theory development and practitioner insights.

The study approaches the topic qualitatively and is implemented in Finland, where doctoral education has recently become a topic of significant policy importance; in less than ten years, doctoral education has gained prominence in research policy, academic career policy and innovation policy (e.g. OECD 2017).

Given the paucity of prior literature examining the topic chosen for this study, in the next section, we consult other relevant literature on reputation to form the theoretical foundation for the study. First, we review the concept of reputation to gain an overview of reputation as a theoretical construct, and secondly, we discuss reputational problems, particularly in the public sector context. Thirdly, we describe the data collection and methods of analysis. Thereafter, we discuss the empirical results, and finally, the article ends with conclusions, theoretical and managerial implications and limitations, and suggestions for future research.

\section{Theoretical background}

\section{Reputation as a concept}

Reputation is a multidisciplinary concept which has been studied in different disciplines (Fombrun and van Riel 1997; Rindova et al. 2005; Suomi 2015). In the current study, we approach the concept from the marketing and management perspective. Regarding definitions of reputation, not surprisingly, those used in management literature approach it on the organisational level and consider the focal objects of reputation to be organisations (e.g. Alessandri et al. 2006; Bromley 2000; Chun 2005; Deephouse and Carter 2005), companies (e.g. Fombrun 1996; Walker 2010) and firms (e.g. Roberts and Dowling 2002). However, and naturally, reputation can also be formed around other objects or entities (see also Herbig and Milewich 1993, p. 18). Indeed, "reputation captures the assessment of an entity" for its stakeholders, where the focal entity may be, for example, an individual, a group of individuals, an organisation, a group of organisations, an industry, a municipality or a country, among others (Winn et al. 2008, p. 36; see also Wæraas 2008; Sataøen and Wæraas 2015 Wæraas et al. 2015).

Previous literature has acknowledged that reputation may differ depending on the stakeholder group perceiving it, for example customers versus suppliers (Walker 2010), and even within the same stakeholder group (Balmer and Greyser 2006). It may also vary among different organisational units; for instance, in the context of higher education, distinct schools and faculties may have varying reputations (e.g. Hemsley-Brown and Goonawardana 2007). However, although there are multiple levels of reputation, definitions typically refer to overall reputation, suggesting that reputation is a combination or average of stakeholders' distinct views (e.g. Chun 2005; Fombrun 1996; Herbig and Milewich 1993; Roper and Fill 2012). As reputation refers to views held by multiple stakeholders, both internal and external, it is socially constructed (Walker 2010). In the current study, we adopt the definition proposed 
by Roper and Fill $(2012$, p. 5), who described reputation as "a combination of the views and impressions of many different people, not unanimously held, but in general". Thus, we consider reputation as an assessment (Barnett et al. 2006).

Winn et al. (2008) concluded that reputation can be based on experiences but also on any other communication or symbolism (see also Fombrun 1996). Thus, perceiving an object as having a certain kind of reputation does not necessarily require personal experience with the object, as may also sometimes be the case with employers in the non-academic labour market when they assess doctorate holders.

People attribute certain reputations to many things in daily life. For example, in the workplace, reputations are presumably connected to individuals' ability to do their work effectively and to be collaborative and helpful to others (Zinko et al. 2012). Thus, we turn to Lawrence (1998, p. 1103) who maintained that "reputation acts as a strategic resource, not only for individual members, but for the community as a whole", where people may have similar work identities. Winn et al. (2008, p. 37) come close to that idea, referring to reputation management at the collective level as "all activities and behaviour undertaken by members of a collective to deliberately alter judgments about the reputation of the collective". Although Winn et al. (2008) used collective reputation management to refer to activities undertaken by a group of firms to enhance their collective reputation, this definition is also pertinent to the reputation management of groups of doctorate holders in building a favourable reputation and overcoming possible reputational problems.

\section{Reputational problems}

Because of the lack of previous studies discussing potential reputational problems related to doctorate holders, it was considered useful first to look into the literature discussing reputational problems in the context of the public sector, as Finnish university degrees and careers belong to the realm of publicly managed universities. Wæraas and Byrkjeflot (2012) in their conceptual study identified five particular problems related to the reputation management of public sector organisations: politics, consistency, charisma, uniqueness and excellence.

The politics problem relates to the fact that public organisations are instruments of elected bodies in implementing public policies. This means that public sector organisations' strategies, visions and mission cannot differ from the political mandate under which they operate. It also indicates that public organisations must work with the mission they have been assigned, whether citizens like it or not. This implies challenges for reputation management (Wæraas and Byrkjeflot 2012). Kuoppakangas et al. (2019) adopted Wæraas and Byrkjeflot's (2012) categorisation and applied it in the context of public higher education organisations by gathering empirical data. In public higher education, the politics problem is visible in issues such as public ownership and the steering which guides the formulation of a university's strategy as well as shrinking core funding and the search for external funding, among others.

Organisations with a favourable reputation are typically those which are consistent in their values, identities and self-presentation. However, that is often problematic for public sector organisations, as they are often characterised with multiple identities, employ a range of professionals and deal with a variety of priorities and values, some of which are contradictory and inconsistent (Wæraas and Byrkjeflot 2012). Regarding higher education organisations, the consistency problem becomes visible, for instance, in terms of duality between different types of employees as well as in differing identities and the self-presentation of faculties, sciences and disciplines (Kuoppakangas et al. 2019; see also Ylijoki and Henriksson 2017). 
As regards the charisma problem, it is suggested that a favourable, strong reputation is a result of an organisation's ability to build emotional appeal with its customers and other stakeholders (Fombrun and van Riel 2004; Wæraas and Byrkjeflot 2012). Organisations with a strong reputation are said to have some kind of "charisma" (W raas 2009; Wæraas and Byrkjeflot 2012). However, many public sector organisations tend to lack charisma, often because they cannot choose their customers and environments, as they are expected to serve everybody equally. Public organisations also often deal with serious problems which are not likely to disappear, such as poverty, social problems and crimes, among others (Wæraas and Byrkjeflot 2012). For higher education organisations, the charisma problem might mean, for example, challenges in providing and transferring timely and applicable knowledge for stakeholders outside academia or finding a common language with them (Kuoppakangas et al. 2019).

Regarding the uniqueness problem, organisations with a strong reputation are typically able to differentiate themselves and be unique (Wæraas and Byrkjeflot 2012; see also Roper and Fill 2012). Public organisations, on the other hand, are often perceived as rather similar, since they are political and hierarchical entities and are often not expected to compete with each other to find ways of differentiating themselves (Wæraas and Byrkjeflot 2012). Competition between public universities may result in uncertainty for those working in universities outside centres of growth (Kuoppakangas et al. 2019).

One presumption in the literature about reputation is that being excellent implies that one is superior to others; thus, reputation is comparative. Many public sector organisations have problems gaining an excellent reputation. As their common mission is to serve the public interest, aiming at an excellent reputation would suggest pursuing a wish to be superior to others involved in the same mission (Wæraas and Byrkjeflot 2012; Walker 2010).

\section{Methodology}

The data for this study were gathered through an online survey as a part of a larger research project conducted in Finland in 2018 to explore how and why academics exit universities (see also Suomi et al. 2019). The survey questionnaire was first tested and was then amended according to feedback. Thus, an invitation to take part in the survey was sent to 4442 respondents. A reminder to complete the survey was sent to the respondents before the deadline. In total, 1226 respondents $(28 \%)$ answered the survey. The survey as a whole comprised 50 questions (including those related to background variables). Of the 50 questions, five were open-ended questions or pairs of questions. One of these five questions or pairs of questions was for respondents' feedback on the survey, and others related to the topic of the survey.

In the current paper, we concentrate on the respondents' verbal answers to one pair of openended questions in the survey, namely:

Are academic university careers and doctoral degrees respected in work life outside academia? How would you describe employers' perceptions of university work? $(N=$ 828).

Out of 828 respondents who answered the above-mentioned pair of open-ended questions, $48.2 \%$ were women, $50.2 \%$ were men and $1.6 \%$ belonged to the group "Other/I do not want to say" (Appendix 1). Age groups are shown in Appendix 2; the biggest age group was 35- 
44 years old (38.1\%). Appendix 3 shows the employment status of the respondents; $81.1 \%$ were employed. One out of three respondents (32.2\%) (see Appendix 4) were working again in academia. The respondents represented the following disciplines: natural sciences, technology, medicine and health science, agriculture and forestry, social sciences and "other" (Appendix 5). However, in this qualitative study, the findings are not organised based on the background variables, which is more common in a quantitative study (e.g. Patel 2009). Instead, this qualitative content analysis aims at a conceptualisation of the phenomenon under study (see e.g. Collier and Mahon 1993).

The first phase of the analysis was to read the material through carefully to obtain a general impression of it. This phase also included underlining key phrases and identifying quotes which somehow seemed important (Ryan and Bernard 2003). As shown above, the pair of questions did not use the term "reputation", as this was not the initial aim of the larger research project. However, the authors' pre-understanding of the concept of reputation led them to recognise that much of what the respondents described was related to reputation, especially as regards reputational problems (Silverman 2001; see also Kuoppakangas et al. 2019; Suomi et al. 2019).

Thus, in the second phase of the analysis, it was considered useful to re-examine the empirical data in light of the literature on reputation, and particularly the categorisation introduced by Wæraas and Byrkjeflot (2012). As is common in a qualitative study, we decided to ask new questions of the data, in this case by employing the reputation literature (Corti and Thompson 2007, p. 302). The purpose of the study was formulated to explore doctorate holders' perceptions of the non-academic labour market and reputational problems they relate to their employment. This phase of the analysis included a search for patterns in the data by coding the text with different colours (see also Miles and Huberman 1994; Creswell 2003).

In the third phase, based on colour codes, the data were grouped into different thematic categories to capture the meanings of the empirical data (Ryan and Bernard 2003; Silverman 2011). When the qualitative content analysis began, we did not, as such, have predetermined notions or theoretical categories from prior theory to guide our analysis. Thus, the analysis was a data-driven, inductive process (e.g. Kovács and Spens 2005). However, as we had some preperceptions and theoretical knowledge, particularly with respect to the categorisation of reputation problems on an organisational level by Wæraas and Byrkjeflot (2012); see also Kuoppakangas et al. 2019), the analysis can be considered as following abductive logic (e.g. Kovács and Spens 2005).

In the fourth phase of the analysis, through grouping different thematic categories, six initial categories were constructed from the data (Elo and Kyngäs 2008; Hsieh and Shannon 2005). This phase also included going back and forth between theory and empirical data in the spirit of abductive reasoning (Kovács and Spens 2005; see also Dubois and Gadde 2002). Confluence with prior theory is discussed in the Discussion section. The categories were titled to describe the nature of the reputational problem, as follows (see also Wæraas and Byrkjeflot 2012):

(1) politics problem

(2) oversupply problem

(3) theoreticality problem

(4) overeducation problem

(5) consistency problem

(6) communication problem 
During the analysis, it became evident that the problems were intertwined rather than isolated. Hence, in the fifth phase of analysis, we combined categories which were closely linked. Problems 1 and 2 were amalgamated, as were problems 3 and 4 . This resulted in four final categories of reputational problems related to oversupply, overeducation, consistency and communication.

To validate the findings, authentic extracts from the data are provided (Silverman 2001). Extracts were carefully translated from Finnish to English by one of the authors so as not to lose the tone of the answers (except ones that had been written in English in the first place). As was the whole article, the quotations were also later checked by a native English language editor. After the quotes, in the brackets, a respondent's employment sector is mentioned first, if available (Appendix 4). After that, a respondent's branch of science is provided (Appendix 5).

\section{Findings}

Next, doctorate holders' perceptions on the non-academic labour market are discussed through the four reputational problems which doctorate holders related to their employment outside academia. Overall, in response to the one pair of open questions, "Are academic university careers and doctoral degrees respected in work life outside academia? How would you describe employers' perceptions of university work?" respondents expressed a range of views based on their recruitment experiences and regarding whether, where and by whom doctoral degrees might be assessed as being favourable. Participants also reported their feeling that doctoral degrees were more respected than academic careers or work experience.

The data analysis revealed that doctorate holders related four reputational problems to their employment in the non-academic labour market: 1) the oversupply problem, 2) the overeducation problem, 3) the consistency problem and 4) the communication problem. These are presented in the next sections.

\section{Oversupply problem}

Respondents expressed concern that there might currently be an oversupply of doctorate holders in Finland, suggesting that this oversupply may have a negative impact on employers' assessments of doctorate holders. The oversupply problem was discussed from different perspectives, including doctorate holders feelings of insecurity after graduation and belttightening in terms of budget cuts to universities and research. Participants also pointed to the perceived "inflation" of doctoral degrees, as illustrated by the next quote:

I know doctorate holders who work, for example, as library assistants. I just heard that my ex-colleague, who defended her doctoral dissertation a couple of years ago, started nursing studies. Or are nurses also soon doctorate holders as well? Why bother educate doctors, when there are too many of them and not enough jobs? Being a doctorate holder is not anything special. It is a system created by people, and unfortunately, it has suffered the same kind of inflation as matriculation exams a couple of decades ago. (Unemployed/Outside of labour force, Natural sciences)

Respondents also reported a perceived disregard towards doctorate holders by the government. Unfortunately, even the highest-level politicians in Finland seem to assess academics negatively and held stereotypes of them. For example, in 2015, the prime minister of that time 
criticised academics by referring to them in the media as "all kinds of adjuncts", a phrase which quickly became popular as a degrading generic term for academics (see Palonen 2017). As one respondent described it:

In the last years, comments from politicians have been confusing. Presumably, these negative comments about science and academia have also impacted people in work life outside academia as well as other citizens. This direction is totally wrong. Scientific research is a different thing from opinions. University budget cuts also speak to the decrease in appreciation. (Unemployed/Outside of labour force, Social sciences)

It has been argued that the oversupply of graduating doctors in Finland had created vast competition for positions both inside and outside academia. Cuts in university budgets were considered indicative of a decrease in appreciation for higher education in general.

\section{Overeducation problem}

Overall, there seemed to be a consensus among respondents that doctorate holders seem to be considered too theoretical and inefficient by employers in the non-academic labour market, particularly in private sector companies. Accordingly, doctorate holders' perception of the nonacademic labour market was that master's degree holders are often preferred to doctorate holders. Respondents mentioned that universities appear to suffer from a reputation of inefficiency, often attributed to public sector organisations in public discussions by stakeholders outside academia. Doctorate holders, in turn, become bearers of the same reputation, particularly if they also continue their academic careers after completing their doctoral studies. Some of the respondents considered it even more difficult to transfer to work outside academia later than it would be to do it soon after one's doctoral graduation. Respondents also expressed the opinion that in the non-academic labour market, a job candidate with a doctoral degree might be seen as a threat, because employers may feel uncomfortable dealing with people who have obtained such degrees. Indeed, many felt that supervisors do not want to hire people who are more educated than they are. Consequently, some respondents mentioned that they had not told recruiters about their doctoral degrees when applying for jobs in the non-academic labour market. For example:

Doctorate holders are being regarded as too educated. They are usually also regarded as theoreticians who do not have manual skills and who do not have good social skills. They just stay put alone in their office at their computer. At worst, doctorate holders are considered some kind of a threat. For example, when I was in practical training included in my studies for a new occupation, I was told to withhold [the fact that] that I have a doctoral degree in order to attain a job interview. Some employers/line managers may feel that a person with a doctoral degree is a threat to their own egos, if they themselves hold "only" a master's or licentiate's degree. Because of that, they might refrain from selecting you for the job, although you would be otherwise competent and commendable for the job related to your new occupation. (Public sector, Medical and health sciences)

It is not understood that a doctorate holder can be a link between research and practice. I continuously face prejudices against doctorate holders. When I applied for work after my doctoral degree, I eventually did not mention that I am a doctorate holder. (Sector missing, Engineering and technology) 
While a doctoral degree was considered necessary to be promoted within an academic career, the situation in the non-academic labour market was perceived as notably different. Respondents described having to palliate the reputation of doctorate holders and related stereotypes when applying for work in the non-academic labour market. Many said that it seemed that master's degree holders were considered to have more practical skills and to be less expensive to hire than doctorate holders.

There is a quite extended image in the private sector that a PhD is conducted by visionary people with few common sense skills needed in business. Having a PhD has, for some people, the meaning that your working habits are less than optimal. (Private sector, Humanities)

It was reported, for example, that after completing their doctoral degree, individuals had difficulty getting jobs from comprehensive schools, despite having previous experience working there.

Many held the view that this image of doctorate holders living in "ivory towers" and knowing only about research is a prejudiced and outdated stereotype:

Maybe they [employers in the non-academic labour market] respect [doctorate holders], but the attitude might be something like: Doctorate holders tinker with one issue. Maybe it is not noticed that this work [university work] also requires an enormous amount of different kinds of know-how outside one's own specific research field: data searching, presentation skills, collaboration, teaching skills, IT skills and capabilities of ongoing learning and development. (University, Medical and health sciences)

Employers' perceptions of university work are often derogatory and arrogant. (University, Social sciences)

Some respondents even reported experiencing bullying and derogatory comments from colleagues in workplaces outside academia because of their doctoral degrees. Indeed, sadly, some felt that it was better not to tell colleagues outside of academia about their doctorate holders.

I think it is appreciated [doctoral degree], but often it is considered snobbish and not as "real" work. (Unemployed/Outside of labour force, Social sciences).

Often one hears mocking, "doctorate holders are not needed here to wise off", but maybe a doctoral degree gives some kind of credibility. (Unemployed/Outside of labour force, Other)

Respondents also noted that most available jobs in the non-academic labour market do not require a doctoral degree. Resulting from this, respondents surmised that employers may think that a doctorate holder will not engage with a job outside academia and will either leave for better positions or return to academia.

Finally, respondents suggested that doctoral degrees may not be a disadvantage in acquiring work in the non-academic labour market as long as the candidate is able to apply her/his theoretical knowledge in practice to meet a company's practical problems. However, many felt that applicants with doctoral degrees must exert extra effort to convince employers of their skills. It was felt, particularly based on their recruitment experiences, that employers do not appreciate applicants whose working experience comes solely from the university context and that they might consider such applicants to be lacking in the necessary practical experience and skills. 


\section{Consistency problem}

Respondents expressed a variety of views concerning whether doctoral degrees are valued in non-academic labour markets. Several respondents felt that doctoral degrees are not respected outside academia at all, while others suggested that they are valued, but not necessarily unanimously by all employers, organisations and industries. Further, respondents suggested that in different countries appreciation varies. It was also noted that the university in which one's academic career has been conducted may impact a doctorate holder's reputation; however, this view was not unanimous. The situation might differ for countries with more fragmented university sectors which include both public and private sector institutions.

With respect to appreciation, respondents mentioned that doctoral degrees might be valued in expert tasks in public sector organisations but that the same might not be true within private sector companies. Exceptions could include, for example, private research companies or other large (international) companies which devote resources to research and development departments and/or international sales. The following quote demonstrates a view held by several respondents working in university hospitals:

Academic careers and doctoral degrees are appreciated in my own field of work. I work at a university hospital and, for leading tasks, a title of adjunct professor or a doctoral degree is required (deputy chief physician, associate chief physician). My current employer has a realistic view of university work. (Public sector, Medical and health sciences)

In addition to the type or industry of the employing company, many respondents felt that the field of one's doctoral degree also impacts the reputation of the degree. This inconsistency was described by one of the respondents as follows:

... a lot depends on the field. It is easy to appreciate it when it is more directly connected to the business world (economics, social sciences, applied sciences, etc.); when the PhD title is in a more theoretical/pure research subject, then it is more rarely appreciated. You need a smart employer to acknowledge the importance of the forma mentis [form of mind] a "theoretical" PhD gives (critical thinking, quick learning and adaptability skills, etc.). (Private sector, Natural sciences)

Respondents also discussed how the backgrounds of employers and line managers might impact their assessments of doctorate holders. Many suggested that line managers and employers who, themselves, had high levels of education were more supportive:

It depends a lot on employer and line managers or colleagues. Usually, people who have a university education will appreciate their peers, but people who have graduated from other schools (e.g. vocational school)—not necessarily. Also, one's field has an impact on how one can get appreciation; a person who has a doctoral degree from information technology is maybe considered more useful than a humanist or philosopher. (Unemployed/ Outside of labour force, Social sciences)

It was also argued that in Finland, doctoral degrees are not valued either inside or outside academia to the same extent as in many other countries. Thus, some of the respondents had moved abroad, for example to Western Europe or to major Englishspeaking nations: 
Appreciation abroad is at a totally different level compared to Finland. Top researchers are being competed for, and universities cannot make competent researchers stay. We do not have competition for researchers between universities, not to mention firms. (Unemployed/Outside of labour force, Natural Sciences)

\section{Communication problem}

Clearly, the respondents held an opinion that the awareness of doctorate holders' competencies should be raised among employers in the non-academic labour market. Respondents indicated that based on their recruitment experiences outside academia, there seem to be several prejudices against doctorate holders and that assessments of doctorate holders often seem outdated and one-sided. They suggested that doctorate holders themselves could be more active in communicating and opening up their competencies and skills, for example with respect to their readiness to manage projects, network, write and work in an international environment. As one respondent described it:

I think [appreciation of doctorate holders] is more related to the person in question and how s/he can market herself/himself. (Working abroad, Natural Sciences)

Respondents suggested that if more doctorate holders gained employment in the non-academic labour market, the market would develop a better understanding of their competencies. However, many also felt that it was difficult for doctorate holders even to have the opportunity to prove their competencies in the first place, as the doctoral degree's reputation prevented them from getting jobs outside academia. Thus, in addition to doctorate holders' own activities, the respondents called for universities to engage in more active communication to increase awareness of doctorate holders' competencies. Further, they suggested reconsidering some of the current titles (e.g. doctoral student, specialist researcher) for faculty members, as some Finnish universities have already done:

Research work during doctoral studies is not seen as work experience, although it is ... university itself can be partly blamed for that, as universities call those who do doctoral studies doctoral students and not junior researchers, for example. (University, Natural Sciences)

In addition, current trends in academia (see e.g. Kallio 2014; Kuoppakangas et al. 2019), such as increasing demands for publishing in leading international journals, were believed to further widen the gap between academia and stakeholders outside academia. This perception is evident in the following extracts:

Appreciation of a doctoral degree can be improved only if research is understood and persons [researchers] are known outside academia. The current emphasis on publishing and getting among the 100 best [universities] only drives universities further from business life. (Sector missing, Natural Sciences)

Doctorate holders' competencies are not known and identified. Particularly, bigger organisations in social work and healthcare, where lots of expert and development work is done, would be suitable employers for doctorate holders. (Third sector, Agriculture) 


\section{Discussion and conclusions}

The purpose of the study was to explore doctorate holders' perceptions of the non-academic labour market and reputational problems they relate to their employment, a topic which has been understudied in previous research. The data were gathered from a group which has been largely ignored in previous studies: doctorate holders who have exited academia (see also Kuoppakangas et al. 2019; Suomi et al. 2019). Thus, the study contributes novel knowledge of reputation management in terms of both theory development and practitioner insights.

The results show that doctorate holders consider their reputation outside academia to be rather weak. Indeed, based on our findings, it appears that employers may form a certain kind of image of doctorate holders with no experience of their own in employing doctorate holders or without other kinds of personal experience. This is in line with prior studies suggesting that perceiving an object as having a certain kind of reputation does not necessarily require personal experience with the object, as it may also be based on different kinds of symbolism and communication (e.g. Winn et al. 2008), such as word of mouth (e.g. Vidaver-Cohen 2007). Therefore, activities and behaviours designed to favourably alter doctorate holders' reputation as a group to meet modern private and public sector organisations' needs are important for both doctorate holders and universities (see also Winn et al. 2008).

As its main theoretical contribution, the study unravels four reputational problems which doctorate holders relate to their employment, which are discussed next, together with policy and managerial implications.

The oversupply problem refers to the possible current oversupply of graduating doctors in Finland. Doctoral education has recently achieved a more important role as an aspect of research policy, scientific career policy and innovation policy in Finland (e.g. OECD 2017). Our data suggest that the number of doctorate holders who graduate from Finnish universities each year might be too large in relation to the availability of academic positions in universities. This finding is in line with OECD statistics, which show that in 2015, Finland had the highest unemployment rate for people with doctoral degrees amongst all OECD countries. Relatively high unemployment amongst people with doctoral degrees can be at least partly explained by a mismatch between the supply of doctoral expertise and industry's knowledge demands for advanced researchers, the lack of effective professional networks of doctorate holders and the low level of mobility between the academic and non-academic sectors (Holopainen 2017; OECD 2017; Sainio 2010). The number of doctoral degrees has also increased rapidly over the past decade. Compared to 2006, an additional 341 (24.2\% more) doctors graduated in 2017. This increase has created challenges related to adapting the labour market demand (both academic and non-academic) to meet the increased supply (Vipunen Education Statistics Finland 2018).

Much of what is discussed above in relation to the oversupply problem relates to politics, and it thus comes close to the reputational problem identified by Wæraas and Byrkjeflot (2012), namely the politics problem (see also Kuoppakangas et al. 2019). As regards our study, and as discussed in the section on methodology, we also identified the politics problem, but it was amalgamated with the oversupply problem in a later phase of the data analysis, as the contents of these two categories were so close to each other.

Our findings imply that for doctorate holders, obtaining a job from non-academic labour markets is often problematic. Accordingly, a portion of the doctorate holders in our sample suffered unemployment (Appendix 3). However, a doctorate holder being forced to accept a job which does not require a doctoral degree (or any academic degree) may dilute respect for doctoral degrees in the long term, thus resulting in a reputational problem for doctoral degrees. 
Our results are in line with Larson et al.'s (2014) US study showing that the academic job market has become increasingly competitive and that it is gradually becoming more difficult for doctorate holders to obtain tenure-track academic positions. Thus, better mobility between the academic and the non-academic labour market would be important for doctorate holders.

Finland has gained a positive reputation in the international media for its highly educated population and equal opportunities as well as its positive attitude towards education and lifelong learning (e.g. BBC 2017). Thus, it is paradoxical that many Finnish doctorate holders feel that their degrees are not appreciated or have even disadvantaged them in non-academic labour markets. Facing challenges at home, an increasing number of Finnish doctorate holders are moving abroad, creating a "brain drain" in which more people with doctoral degrees are moving away from Finland than are moving into Finland (e.g. Acatiimi 2017; Statistics Finland 2017). It would be useful at a policy level to reconsider the number of doctors graduating in Finland. Government has the possibility of adjusting the performance-based funding model to compensate universities less per doctoral graduate and at the same time to offer stronger incentives for doctoral employment outside academia (e.g. by introducing a doctoral employability indicator in the funding formula).

The growing number of doctoral degrees, especially in Europe, has raised concerns about the negative consequences of their possible misallocation in the labour market, especially in view of recent signs of saturation in the academic job market (Auriol 2010; Di Paolo and Mañé 2016). Outside Europe, for example, the oversupply of doctorate holders has been studied in Australia (Molla and Cuthbert 2015). In the natural sciences, the cases often referred to as examples of oversupply are Japan, China and the US. Japan is an example of an aggressive policy which tripled the production of doctors. China has been used as a case example on the quality issues related to massification in doctoral education, while the US has been seen as an example of supply-driven demand causing many holders of doctoral degrees to obtain positions for which they do not require their qualifications (Cyranoski et al. 2011).

With respect to the overeducation problem, the doctorate holders believe that in the nonacademic labour market, they are often considered too theoretical and overeducated. The data also indicate that outside academia, doctorate holders might suffer a reputation of inefficiency, often related to perceptions of public sector organisations in the media and among the general public (e.g. Luoma-aho 2008). These perceptions may lead to negative impressions of doctorate holders, even though, given the resources available, the Finnish university sector has been shown to work effectively in global comparisons (see Williams and Leahy 2018). It could be interpreted that doctorate holders, as a group, have difficulties appealing to employers in the non-academic labour market, due to negative views and impressions related to the public sector. This comes close to the ideas of Wæraas and Byrkjeflot (2012), who have discussed negative views of public sector organisations in relation to the charisma problem (see also Kuoppakangas et al. 2019).

On a practical level, more initiatives like Podoco (PostDocs in Companies; a joint initiative of Finnish universities, industry and foundations) could help match doctorate holders with companies to foster the transfer of theory to practice, thus improving doctorate holders' employment outside academia (Podoco 2018). The role of human resource management in supporting doctorate holders' career development both inside and outside academia should also be reconsidered in collaboration with professors supervising doctoral students. It is also important to popularise science more effectively and to take part in societal discussions in a timely manner, that is, to translate research results into practice (see also Suomi et al. 2019).

The consistency problem is rooted in the fact that doctorate holders as a group currently fall short in forming a favourable and consistent reputation. Since our study detected and discussed the consistency problem at the doctoral level, it thus adds to the conceptual study of Wæraas and 
Byrkjeflot (2012), which identified the consistency problem of reputation management in the public sector on an organisational level, and to the work of Kuoppakangas et al. (2019), who discussed in their empirical study the consistency problem of reputation management with respect to higher education organisations. Universities, like other public sector organisations in Finland, are expected to have similar values, services and quality, and this also applies to doctoral education (see also Wæraas and Byrkjeflot 2012). Therefore, it should be possible to build a favourable and more consistent reputation for the different fields of doctorate holders in the long run.

However, in building a collective reputation for doctorate holders, it is important to remember that not all inconsistencies are related to the doctorate holders themselves (e.g. the doctorate holder's field or alma mater), as the doctorate holders reported that some employers' own backgrounds (e.g. education) seem to make difference in the recruitment processes. To build a favourable and consistent collective reputation for doctorate holders, it might be useful for universities and associations of doctorate holders to pay more attention to collective reputation management (Winn et al. 2008) to alter views about and impressions of doctorate holders. It would be beneficial to elaborate on which are the core competencies and skills which employers value, which doctorate holders share regardless of their field, and then to communicate and promote these skills more actively and consistently (W raas and Solbakk 2009).

Indeed, regarding the communication problem, the doctorate holders reported feeling that outside of academia, there seems to be a lack of adequate understanding of doctorate holders' competencies and how they could be useful for companies and other organisations. Accordingly, both universities and doctorate holders themselves could do more to build a more favourable reputation for doctorate holders as a group. Employers may not consider doctoral studies as "real" work experience until they know more about the competencies which research work requires. It also seems that doctorate holders do not enjoy a favourable differentiation from master's degree holders in work life outside academia (see also Wæraas and Byrkjeflot 2012 for the uniqueness problem of public sector organisations).

To alter the reputation of doctorate holders being in the "ivory tower", the competencies provided by doctoral education should be explicitly mapped and then communicated outside academia. This will require effective communication to improve respect towards and trust in doctorate holders' competencies among employers in private, public and voluntary sector organisations. Those who plan postgraduate courses at the doctoral level could pay more attention to fostering doctoral students' communication skills in productising their competencies.

Regarding the limitations of this study, the data were gathered from doctorate holders, as we were particularly interested in doctorate holders' perceptions of the non-academic labour market and reputational problems they relate to their employment. It was considered valuable to concentrate on the perceptions of a group that has been largely neglected in previous studies: doctorate holders who have exited academia (see also Suomi et al. 2019). However, future study could continue to gather data from employers representing non-academic labour markets to shed further light on the topic and to compare results with the current study.

Further, as the current study was conducted in Finland, the results could best be juxtaposed against those for other Nordic countries or for countries facing similar problems in the dynamics of doctoral employability. Thus, it would be useful to expand the research and explore doctorate holders' perceptions of the non-academic labour market, and how they make sense of their collective reputation outside academia, in other countries and cultures. This would be particularly useful, as our results indicate that the reputation of doctorate holders might differ across countries.

Acknowledgements The authors wish to thank "Exiting academics in networked knowledge-societies -research project and Academy of Finland for funding this study. 
Funding Open access funding provided by University of Turku (UTU) including Turku University Central Hospital.

\section{Appendix}

Table 1 Gender

\begin{tabular}{llll}
\hline & & $\mathrm{N}$ & $\%$ \\
\hline Valid & Woman & 396 & 48.2 \\
& Man & 413 & 50.2 \\
& Other/ I don't want to say & 13 & 1.6 \\
& Total & 822 & 100.0 \\
Missing & & 6 & \\
Total & & 828 & \\
\hline
\end{tabular}

Table 2 Age Group

\begin{tabular}{llll}
\hline & & $\mathrm{N}$ & $\%$ \\
\hline Valid & Age 34 or below & 27 & 3.3 \\
& Age 35-44 & 313 & 38.1 \\
& Age 45-54 & 231 & 28.1 \\
& Age 55-64 & 146 & 17.8 \\
& Age 65 or more & 104 & 12.7 \\
Missing & Total & 821 & 100.0 \\
Total & & 7 & \\
\hline
\end{tabular}

Table 3 Employment Status

\begin{tabular}{llll}
\hline & & $\mathrm{N}$ & $\%$ \\
\hline Valid & Employed & 669 & 81.1 \\
& Unemployed/ In process of employment integration & 156 & 18.9 \\
& $\quad$ measures/ Outside of labour force & & 100.0 \\
Missing & Total & 825 & 3 \\
Total & & 828 & \\
\hline
\end{tabular}

Table 4 Employment Sector

\begin{tabular}{llll}
\hline & & $\mathrm{N}$ & $\%$ \\
\hline Valid & University & 255 & 32.2 \\
& Private sector & 171 & 21.6 \\
& Public sector & 122 & 15.4 \\
& Third sector & 13 & 1.6 \\
& Unemployed/ Outside of labour force & 156 & 19.7 \\
& Working abroad & 76 & 9.6 \\
Missing & Total & 793 & 100.0 \\
Total & & 35 & \\
\hline
\end{tabular}


Table 5 Branch of Science (First Doctoral Degree)

\begin{tabular}{llll}
\hline & & $\mathrm{N}$ & $\%$ \\
\hline Valid & Natural sciences & 290 & 35.8 \\
& Engineering and technology & 100 & 12.3 \\
& Medical and health sciences & 106 & 13.1 \\
& Social sciences & 197 & 24.3 \\
& Humanities & 92 & 11.3 \\
& Agriculture & 18 & 2.2 \\
& other & 8 & 1.0 \\
Missing & Total & 811 & 100.0 \\
Total & & 17 & 828 \\
\hline
\end{tabular}

Open Access This article is licensed under a Creative Commons Attribution 4.0 International License, which permits use, sharing, adaptation, distribution and reproduction in any medium or format, as long as you give appropriate credit to the original author(s) and the source, provide a link to the Creative Commons licence, and indicate if changes were made. The images or other third party material in this article are included in the article's Creative Commons licence, unless indicated otherwise in a credit line to the material. If material is not included in the article's Creative Commons licence and your intended use is not permitted by statutory regulation or exceeds the permitted use, you will need to obtain permission directly from the copyright holder. To view a copy of this licence, visit http://creativecommons.org/licenses/by/4.0/.

\section{References}

Acatiimi (2017). Osaamisvaihtotase yhä enemmän miinuksella. http://www.acatiimi.fi/8_2017/3.php. Accessed 23 August 2018.

Alessandri, S. W., Yang, S.-U., \& Kinsey, D. F. (2006). An integrative approach to university visual identity and reputation. Corporate Reputation Review, 9(4), 258-270.

Ali-Choudhury, R., Bennett, R., \& Savani, S. (2009). University marketing directors' views on the components of a university brand. International Review on Public and Nonprofit Marketing, 6(1), 11-33.

Alves, H., \& Raposo, M. (2010). The influence of university image on student behaviour. International Journal of Educational Management, 24(1), 73-85.

Argenti, P. (2000). Branding b-schools: Reputation management for MBA programs. Corporate Reputation Review, 3(2), 171-178.

Aula, H.-M., \& Tienari, J. (2011). Becoming "world-class"? Reputation-building in a university merger. Critical Perspectives on International Business, 7(1), 7-29.

Auriol, L. (2010). Careers of doctorate holders: Employment and mobility patterns. In OECD science, technology and industry working papers 2010/4. Paris: OECD Publishing.

Balmer, J. M. T., \& Greyser, S. A. (2006). Corporate marketing: Integrating corporate identity, corporate branding, corporate communications, corporate image and corporate reputation. European Journal of Marketing, 40(7-8), 730-741.

Barnett, M. L., Jermier, J. M., \& Lafferty, B. A. (2006). Corporate reputation: The definitional landscape. Corporate Reputation Review, 9(1), 26-38.

BBC (2017). Could subjects soon be a thing of the past in Finland? Available at: https://www.bbc. com/news/world-europe-39889523. Accessed 24 August 2018.

Bromley, D. B. (2000). Psychological aspects of corporate identity, image and reputation. Corporate Reputation Review, 3(3), 240-252.

Buchert, S., Laws, E. L., Apperson, J. M., \& Bregman, N. J. (2008). First impressions and professor reputation: Influence on student evaluations of instruction. Social Psychology of Education, 11(4), 397-408.

Chun, R. (2005). Corporate reputation: Meaning and measurement. International Journal of Management Reviews, 7(2), 91-109.

Collier, D., \& Mahon, J. E. (1993). Conceptual "stretching" revisited: Adapting categories in comparative analysis. The American Political Science Review, 87(4), 845-855. 
Corti, L., \& Thompson, P. (2007). Secondary analysis of archived data. In C. Seale, G. Gobo, J. F. Gubrium, \& D. Silverman (Eds.), Qualitative research in practice. London: Sage Publications.

Creswell, J. W. (2003). Research design. Qualitative, quantitative, and mixed methods approaches (2nd ed.). Thousand Oaks, CA: Sage Publications.

Cyranoski, D., Gilbert, N., Ledford, H., Nayar, A., \& Yahia, M. (2011). Education: The PhD factory. Nature News, 472(7343), 276-279.

Deephouse, D. L., \& Carter, S. M. (2005). An examination of differences between organizational legitimacy and organizational reputation. Journal of Management Studies, 42(2), 329-360.

Di Paolo, A., \& Mañé, F. (2016). Misusing our talent? Overeducation, overskilling and skill underutilisation among Spanish PhD graduates. The Economic and Labour Relations Review, 27(4), 432-452.

Dubois, A., \& Gadde, L.-E. (2002). Systematic combining: An abductive approach to case research. Journal of Business Research, 55(7), 553-560.

Elo, S., \& Kyngäs, H. (2008). The qualitative content analysis process. Journal of Advanced Nursing, 62(1), $107-115$.

Fombrun, C. J. (1996). Reputation. Realizing value from the corporate image. Boston: Harvard Business School.

Fombrun, C. J., \& van Riel, C. B. M. (1997). The reputational landscape. Corporate Reputation Review, 1(1-2), 5-13.

Fombrun, C. J., \& van Riel, C. B. M. (2004). Fame \& fortune: how successful companies build winning reputations. Upper Saddle River, NJ: Pearson Education.

Haapakorpi, A. (2017). Doctorate holders outside the academy in Finland: Academic engagement and industryspecific competence. Journal of Education and Work, 30(1), 53-68.

Hancock, S., \& Walsh, E. (2016). Beyond knowledge and skills: Rethinking the development of professional identity during the STEM doctorate. Studies in Higher Education, 41(1), 37-50.

Hemsley-Brown, J., \& Goonawardana, S. (2007). Brand harmonization in the international higher education market. Journal of Business Research, 60(9), 942-948.

Herbig, P., \& Milewich, J. (1993). The relationship of reputation and credibility to brand success. Journal of Consumer Marketing, 10(3), 18-24.

Holopainen, H. (2017). Tohtoreiden monet urat. Tohtoreiden osaamisen hyödyntäminen työelämässä yliopistojen ulkopuolella. Helsinki: Sivistystyönantajat.

Hsieh, H-F., \& Shannon, S. E. (2005). Three approaches to qualitative content analysis. Qualitative Health Research, 15(9), 1277-1288.

Kallio, K-M. (2014). “Ketä kiinnostaa tuottaa tutkintoja ja julkaisuja liukuhihnaperiaatteella...?” Suoritusmittauksen vaikutukset tulosohjattujen yliopistojen tutkimus-ja opetushenkilökunnan työhön. Turku School of Economics, Series A-1: 2014. Turku, Finland: Juvenes Print.

Kovács, G., \& Spens, K. M. (2005). Abductive reasoning in logistics research. International Journal of Physical Distribution \& Logistics Management, 35(2), 132-144.

Kuoppakangas, P., Suomi, K., Stenvall, J., Pekkola, E., Kivistö, J., \& Kallio, T. J. (2019). Revisiting the five problems of public sector organisations and reputation management - The perspective of higher education practitioners and exacademics. International Review on Public and Nonprofit Marketing, 16(2-4), 147-171.

Larson, R. C., Ghaffarzadegan, N., \& Xue, Y. (2014). Too many PhD graduates or too few academic job openings: The basic reproductive number R0 in academia. Systems Research and Behavioral Science, 31, $745-750$

Lawrence, T. B. (1998). Examining resources in an occupational community: Reputation in Canadian forensic accounting. Human Relations, 51(9), 1103-1131.

Luoma-aho, V. (2008). Sector reputation and public organisations. International Journal of Public Sector Management, 21(5), 446-467.

McAlpine, L., \& Emmioğlu, E. (2015). Navigating careers: Perceptions of sciences doctoral students, post-PhD researchers and pre-tenure academics. Studies in Higher Education, 40(10), 1770-1785.

Molla, T., \& Cuthbert, D. (2015). The issue of research graduate employability in Australia: An analysis of the policy framing (1999-2013). The Australian Educational Researcher, 42(2), 237-256.

Miles, M. B., \& Huberman, A. M. (1994). An expanded sourcebook. Qualitative data analysis (2nd ed.). Thousand Oaks, CA: Sage Publications.

Ministry of Education and Culture (2016). Miten tohtorit työllistyvät (Employment situation of people with PhDs) Opetus- ja kulttuuriministeriön julkaisuja 2016:3. http://julkaisut.valtioneuvosto. fi/bitstream/handle/10024/64972/MitenTohtoritTyollistyvat.pdf. Accessed 17 March 2018.

OECD. (2017). OECD reviews of innovation policy: Finland 2017. Paris: OECD Publishing.

Palonen, E. (2017). Finland. European Journal of Political Research. Political Data Yearbook, 56(1), 92-98.

Patel, P. (2009). Introduction to quantitative methods. https://hls.harvard.edu/content/uploads/2011/12 /quantitative_methods.pdf. Accessed 20 March 2020.

Podoco (2018). PostDocs in Companies. https://www.podoco.fi/about/. Accessed 22 August 2018. 
Rindova, V. P., Williamson, I. O., Petkova, A. P., \& Sevier, J. M. (2005). Being good or being known: An empirical examination of the dimensions, antecedents, and consequences of organizational reputation. Academy of Management Journal, 48(6), 1033-1049.

Roberts, P. W., \& Dowling, G. R. (2002). Corporate reputation and sustained superior financial performance. Strategic Management Journal, 23, 1077-1093.

Roper, S., \& Fill, C. (2012). Corporate reputation - Brand and communication. Harlow: Pearson Education Limited.

Ryan, G. W., \& Bernard, H. R. (2003). Techniques to identify themes in qualitative data. Field Methods, 15(1), 85-109. https://doi.org/10.1177/1525822X02239569.

Sainio, J. (2010). Asiantuntijana työmarkkinoille. Vuosina 2006 ja 2007 tohtorin tutkinnon suorittaneiden työllistyminen ja heidän mielipiteitään tohtorikoulutuksesta. Aarresaaren julkaisusarja.

Sataøen, H. L., \& Wæraas, A. (2015). Branding without unique brands: Managing similarity and difference in a public sector context. Public Management Review, 17(3), 443-461.

Silverman, D. (2001). Interpreting qualitative data. Methods for analyzing talk, text and interaction (2 $2^{\text {nd }}$ ed.), London: Sage publications.

Silverman, D. (2011). Qualitative research (3rd ed.). London: Sage Publication Ltd..

Statistics Finland (2017). Emigration of educated Finnish citizens bigger than immigration. http://tilastokeskus. fi/til/muutl/2016/02/muutl_2016_02_2017-12-18_tie_001_en.html. Accessed 23 August 2018.

Suomi, K. (2014). Exploring the dimensions of brand reputation in higher education - A case study of a Finnish Master's degree programme. Journal of Higher Education Policy and Management, 36(6), 646-660.

Suomi, K. (2015). Managing brand identity and reputation - A case study from Finnish higher education. (series A-3:2015) [Doctoral dissertation, Turku School of Economics, Juvenes Print, Turku, Finland].

Suomi, K., \& Järvinen, R. (2013). Tracing reputation risks in retailing and higher education services. Journal of Retailing and Consumer Services, 20(2), 207-217.

Suomi, K., Kuoppakangas, P., Hytti, U., Hampden-Turner, C., \& Kangaslahti, J. (2014). Focusing on dilemmas challenging reputation management in higher education. International Journal of Educational Management, 28(4), 461-478.

Suomi, K., Kuoppakangas, P., Stenvall, J., Pekkola, E., \& Kivistö, J. (2019). Revisiting "the shotgun wedding of industry and academia"-Empirical evidence from Finland. International Review on Public and Nonprofit Marketing, 16(1), 81-102.

Thune, T. (2009). Doctoral students on the university-interface: A review of the literature. Higher Education, 58, 637-651.

Vidaver-Cohen, D. (2007). Reputation beyond the rankings: A conceptual framework for business schools research. Corporate Reputation Review, 10(4), 278-304.

Vipunen Education Statistics (2018). University students and degrees. https://vipunen.fi/engb/university/Pages/Opiskelijat-ja-tutkinnot.aspx. Accessed 27 September 2018.

Ylijoki, O.-H., \& Henriksson, L. (2017). Tribal, proletarian and entrepreneurial career stories: Junior academics as a case in point. Studies in Higher Education, 42(7), 1292-1308.

Walker, K. (2010). A systematic review of the corporate reputation literature: Definition, measurement, and theory. Corporate Reputation Review, 12(4), 357-387.

Williams, R., \& Leahy, A. (2018). U21 ranking of national higher education systems. University of Melbourne.

Winn, M., MacDonald, P., \& Zietsma, C. (2008). Managing industry reputation: The dynamic tension between collective and competitive reputation management strategies. Corporate Reputation Review, 11, 35-55.

Wæraas, A. (2008). Can public sector organizations be coherent corporate brands? Marketing Theory, 8(2), 205221.

W raas, A. (2009). On weber: Legitimacy and legitimation in public relations. In Ø. Ihlen, B. van Ruler, \& M. Fredrikson (Eds.), Public relations and social theory: Key concept and figures (pp. 302-322). New York: Routledge.

Wæraas, A., Bjørnå, H., \& Moldenæs, T. (2015). Place, organization, democracy: Three strategies for municipal branding. Public Management Review, 17(9), 1282-1304.

Wæraas, A., \& Byrkjeflot, H. (2012). Public sector organizations and reputation management: Five problems. International Public Management Journal, 15(2), 186-206.

W raas, A., \& Solbakk, M. N. (2009). Defining the essence of a university: Lessons from higher education branding. Higher Education, 57(4), 449-462.

Zinko, R., Ferris, G. R., Humphrey, S. E., Meyer, C. J., \& Aim, F. (2012). Personal reputation in organizations: Two-study constructive replication and extension of antecedents and consequences. Journal of Occupational and Organizational Psychology, 85, 156-180.

Publisher's Note Springer Nature remains neutral with regard to jurisdictional claims in published maps and institutional affiliations. 